\title{
Neonatal hyperammonaemia with complete absence of liver carbamyl phosphate synthetase activity
}

\author{
STEPHANOS MANTAGOS, SOPHIA TSAGARAKI, E. ANN BURGESS, VICTOR \\ OBERHOLZER, TREVOR PALMER, JOANNA SACKS, STATHIS BAIBAS, AND TIMOS \\ VALAES
}

\section{From The Institute of Child Health, St. Sophia Children's Hospital, Athens, and Biochemistry Department, Queen Elizabeth Hospital for Children, London}

SUMmaRY Two newborn infants, male (A) and female (B), with lethal hyperammonaemia are described in the same family. In both, symptoms started on the second day of life. Lethargy and hypotonia were the most prominent initial findings and were followed by convulsions and coma. In both, blood ammonia levels rose to $570 \mu \mathrm{mol} / 1(798 \mu \mathrm{g} / 100 \mathrm{ml})$ a few hours before death, which occurred on the third and fourth day of life respectively. Assay of liver urea cycle enzymes in baby B showed a complete absence of mitochondrial carbamyl phosphate synthetase activity.

Hereditary enzyme defects of the urea cycle have been diagnosed with increasing frequency during the last few years as causes of severe neurological damage or death during infancy and childhood. Five distinct disorders have been described so far, involving each one of the five enzymes of the KrebsHenseleit urea cycle (Levin, 1971; Shih and Efron, 1972; Scriver and Rosenberg, 1973); hyperammonaemia due to carbamyl phosphate synthetase (CPS) deficiency; hyperammonaemia due to ornithine transcarbamylase (OTC) deficiency; citrullinaemia due to argininosuccinic acid (ASA) synthetase deficiency; ASAuria due to ASA lyase deficiency; and argininaemia due to arginase deficiency. All five disorders have a similar clinical picture characterised by protein intolerance, vomiting, seizures, and various degrees of mental retardation associated with hyperammonaemia. It has also recently been recognised that these disorders can cause neonatal death. We report 2 newborn infants with neonatal hyperammonaemia in the same family. In one of them, in which enzyme studies were done, no CPS activity was found.

\section{Case reports}

Case 1. Baby A was a term male, born after a normal pregnancy and uncomplicated delivery, birthweight $3600 \mathrm{~g}$. The mother was 23 , the father 27 years old, and both were apparently healthy. The mother's grandmother and the father's grandfather were first

Received 8 August 1977 cousins. Baby A was the product of the third pregnancy of the mother. The first had resulted in a miscarriage during the fourth month of pregnancy. The second baby was a term male who died 12 hours after birth without definite diagnosis, but with symptoms similar to those of babies $\mathbf{A}$ and $\mathbf{B}$.

Baby $\mathbf{A}$ appeared well at birth. Glucose-water feedings were started and he remained well until the end of the first 24-hour period when he became progressively lethargic, hypotonic, and refused feeds. During the second day his condition deteriorated, with tachypnoea, abdominal distension, and generalised tonic-clonic convulsions. He was transferred to the neonatal unit of this hospital at 40 hours.

On admission he was comatose with frequent episodes of generalised convulsions. The primitive reflexes were lacking. The fontanelle was normal. Palpation of the liver and spleen was difficult because of the abdominal distension. Intravenous glucose $10 \%$ was started and diazepam and phenobarbitone were given for the convulsions. A few hours after admission episodes of apnoea started and intubation with artificial ventilation was required. In spite of protein restriction and supportive measures, the baby died at 56 hours. During the last few hours of life, he expelled a characteristic odour of ammonia during respiration.

Laboratory data included a normal blood count, blood glucose, and serum electrolytes, and calcium. Spinal tap was normal and blood and CSF cultures negative. Chest $x$-ray was normal, and aspartate and alanine transaminases (SGOT and SGPT) were 230 
$100 \mathrm{IU} / 1$ and $15 \mathrm{IU} / 1$ respectively. Blood ammonia 6 hours before death was markedly raised (see Results) with a blood urea at the same time of $3 \cdot 3$ $\mathrm{mmol} / 1$ (19.9 mg/100 ml) (normal 3.3-6.7 mmol/1; $19 \cdot 9-40 \cdot 4 \mathrm{mg} / 100 \mathrm{ml}$ ). Plasma and urine amino acid screening by paper chromatography showed an increase of glutamine with an otherwise normal amino acid pattern. Necropsy examination, both macroscopical and histological, was unremarkable.

Case 2. Baby B was a term female born $2 \frac{1}{2}$ years after baby A. Pregnancy and delivery were uneventful and birthweight was $3600 \mathrm{~g}$. She appeared well after birth, but because of the family history of previous neonatal deaths, associated with hyperammonaemia in the last child, she was transferred immediately to this hospital.

Soon after admission $10 \%$ glucose IV was started, and the blood ammonia 5 hours after birth was raised. Her condition steadily deteriorated while the blood ammonia level rose (see Results). 22 hours after birth she began vomiting. She became progressively lethargic and hypotonic, and at the end of the second day she became comatose. Exchange transfusion with fresh blood was performed without clinical improvement or decrease in blood ammonia. Generalised convulsions followed and she died aged 96 hours.

Laboratory results included a normal blood count, blood glucose, serum electrolytes, calcium, and bilirubin. SGOT and SGPT were 21 and $41 \mathrm{IU} / 1$ respectively and blood urea $3.8 \mathrm{mmol} / 1(22.9 \mathrm{mg} /$ $100 \mathrm{ml}$ ). Two EEGs taken during the first and second days of life showed poor bioelectric activity and low voltage bilaterally. Necropsy examination showed small areas of aspiration pneumonia bilaterally and haemorrhagic infarction at the base of the left lung. No other abnormalities, macroscopical or histological, were detected.

\section{Methods}

Venous plasma ammonia was estimated at the Institute of Child Health, Athens, by the Hyland Blood Ammonia kit test using the Berthelot reaction. The upper limit of normal was considered to be 57 $\mu \mathrm{mol} / 1(80 \mu \mathrm{g} / 100 \mathrm{ml})$. Amino acid screening was done by two-dimensional paper chromatography. Frozen specimens of plasma, deproteinised plasma (Stein and Moore, 1954), urine, and liver were sent to Queen Elizabeth Hospital for Children, London, for further investigation. Quantitative amino acid analysis was made on a Technicon Amino Acid Analyser, using a modification of the standard procedure in order to get reliable estimates of glutamine levels (Palmer et al., 1974).
Liver urea cycle enzymes were determined by the methods of Brown and Cohen (1959), according to the details given in Levin (1971). Liver from baby B was obtained 30 minutes after death and stored at $-30^{\circ} \mathrm{C}$ for 3 months until analysis. $A$ repeat analysis was made after keeping the specimen for a further 3 years at $-70^{\circ} \mathrm{C}$. The OTC was measured at $\mathrm{pH} \mathrm{7.75}$ using conditions found optimal for human liver (Snodgrass, 1968) and the CPS assay was supplemented with excess OTC (Sigma grade) (Snodgrass and DeLong, 1976). This method measures both the mitochondrial form of the enzyme $\left(\mathrm{CPS}_{1}\right)$ which participates in urea cycle metabolism and the cytoplasmic form $\left(\mathrm{CPS}_{2}\right)$ which is involved in pyrimidine synthesis. In the liver the activity of the latter is of relatively little significance (Gelehrter and Snodgrass, 1974).

Urinary excretion of pyrimidine derivatives was investigated by chromatography using the technique of Rinderknecht and Rinderknecht (1965) for urinary pseudouridine. Orotic acid excretion was quantitatively measured by a modification (to be published) of the method of Rogers and Porter (1968), after a purification step using ion exchange resin. Urinary excretion of $\mathrm{N}$-carbamyl compounds was measured by the method of Oberholzer and Palmer (1976). Volatile fatty acids in plasma and urine were determined by gas chromatography, and nonvolatile organic acids in urine screened by paper and thinlayer chromatography.

\section{Results}

Both babies showed a large increase in blood ammonia levels, associated with blood urea levels at the lower limit of normal. In baby $\mathbf{A}$ the blood ammonia was $570 \mu \mathrm{mol} / 1(798 \mu \mathrm{g} / 100 \mathrm{ml}) 6$ hours before death. The various levels of blood ammonia in baby B, correlated with the clinical stage of the disease, are presented in Table 1.

In both babies blood and urine screening for amino acids by paper chromatography showed a large increase in glutamine. These findings were

Table 1 Correlation of clinical picture with plasma ammonia in baby $B$ (upper limit of normal by method used $=57 \mu \mathrm{mol} / \mathrm{l})$

\begin{tabular}{rll}
\hline Age $(h)$ & Symptoms & Plasma ammonia $(\mu \mathrm{mol} / l)$ \\
\hline 5 & None & 93 \\
22 & Vomiting & 224 \\
31 & Lethargy & 226 \\
48 & Coma & 364 \\
56 & Convulsions & 578 \\
72 & Same & 578 \\
\hline
\end{tabular}

Conversion: SI to traditional units-

Ammonia: $1 \mu \mathrm{mol} / \mathrm{l} \approx 1.4 \mu \mathrm{g}$ ammonia nitrogen $/ 100 \mathrm{ml}$. 
confirmed in baby $\mathbf{B}$ by quantitative plasma and urine amino acid analysis. Plasma amino acids in this baby showed a marked increase in glutamine and alanine, with low levels of most of the remaining amino acids, probably secondary to the restriction of protein intake. No citrulline was detected. Analysis of urine amino acids gave a similar picture. The overall amino acid picture was typical of hyperammonaemia.

The activities of hepatic urea cycle enzymes for baby B analysed after 3 months and 3 years' storage are shown in Table 2. No CPS activity was detected on either occasion. OTC activity was decreased compared to the range obtained in our laboratory for biopsy specimens from children (Levin, 1971). When repeat analysis was made after 3 years the viability of the liver tissue was checked by estimation

Table 2 Activity of urea-cycle enzymes in liver of baby $B$

\begin{tabular}{|c|c|c|c|c|}
\hline & Baby $B$ & Control range* & Baby $B$ & Control range \\
\hline Age & $96 \mathrm{~h}$ & Children & $96 \mathrm{~h}$ & $36 \mathrm{~h}-3 \mathrm{yr}$ \\
\hline Sample & $\begin{array}{l}\text { Necropsy } \\
30 \text { min PM }\end{array}$ & Biopsy & $\begin{array}{l}\text { Necropsy } \\
30 \text { min PM }\end{array}$ & $\begin{array}{l}\text { Necropsy } \\
\text { I-53 h PM }\end{array}$ \\
\hline Storage & $\begin{array}{r}3 \mathrm{~m} \text { at } \\
-30^{\circ} \mathrm{C}\end{array}$ & & $\begin{array}{l}3 \text { yr at } \\
-70^{\circ} \mathrm{C}\end{array}$ & $\begin{array}{l}6 \mathrm{w}-5 \text { yr at } \\
-70^{\circ} \mathrm{C}\end{array}$ \\
\hline \multicolumn{5}{|l|}{$\begin{array}{l}\text { Carbamyl } \\
\text { phosphate } \\
\text { synthetase }\end{array}$} \\
\hline $\begin{array}{l}\text { U/g } \\
\text { U/mgp }\end{array}$ & Nil & $180-615(5) \dagger$ & $\begin{array}{l}\mathrm{Nil} \\
\mathrm{Nil}\end{array}$ & $\begin{array}{l}32-200(5) \dagger \\
0 \cdot 35-1 \cdot 51\end{array}$ \\
\hline \multicolumn{5}{|c|}{$\begin{array}{l}\text { Ornithine } \\
\text { transcarbamylase } \\
\text { pH } 7.0\end{array}$} \\
\hline $\begin{array}{r}(\mathrm{U} / \mathrm{g}) \\
\mathrm{pH} \mathrm{8.3}\end{array}$ & 940 & 3950-6550 (13) & & \\
\hline $\begin{array}{c}(\mathrm{U} / \mathrm{g}) \\
\mathrm{pH} 7.75\end{array}$ & 1580 & $3900-9090$ (13) & & \\
\hline $\begin{array}{l}(\mathrm{U} / \mathrm{g}) \\
(\mathrm{U} / \mathrm{mgp})\end{array}$ & & & $\begin{array}{l}3050 \\
24 \cdot 5\end{array}$ & $\begin{array}{l}1520-6320 \\
16 \cdot 7-34 \cdot 3(5)\end{array}$ \\
\hline $\begin{array}{l}\text { ASA synthetase } \\
\text { U/g } \\
\text { U/mgp }\end{array}$ & 14 & $21-43(3)$ & $\begin{array}{l}32 \cdot 8 \\
0.26\end{array}$ & $\begin{array}{l}42-73(5) \\
0 \cdot 26-0 \cdot 54\end{array}$ \\
\hline $\begin{array}{l}\text { ASA lyase } \\
\text { U/g } \\
\text { U/mgp }\end{array}$ & 112 & $100-177(3)$ & $\stackrel{81}{0.66}$ & $\begin{array}{l}54-175(5) \\
0.42-0.95\end{array}$ \\
\hline $\begin{array}{l}\text { Arginase } \\
\text { U/g } \\
\mathbf{U} / \mathbf{m g p}\end{array}$ & 24 & $100-70200$ (4) & $\begin{array}{r}16450 \\
134\end{array}$ & $\begin{array}{r}5730-24000 \\
48-130(5)\end{array}$ \\
\hline $\begin{array}{r}\text { Glucose-6-phosp } \\
\mu \mathrm{mol} P / \mathrm{min} p \\
\mu \mathrm{mol} \mathrm{P} / \mathrm{min} \mathrm{p}\end{array}$ & $\begin{array}{l}\text { phataseł } \\
\text { ser g } \\
\text { eer mgp }\end{array}$ & & $\begin{array}{c}8.5 \\
0.069\end{array}$ & $\begin{array}{l}2 \cdot 4-7.0(5) \\
0.020-0.070\end{array}$ \\
\hline $\begin{array}{l}\text { Protein } \\
\text { (mg/g) }\end{array}$ & & & 123 & 99-184 (5) \\
\hline
\end{tabular}

*Data originally presented by Levin et al. (1969).

+ Numbers in parentheses indicate number of specimens.

$\ddagger$ Tissue viability test.

ASA = argininosuccinic acid; $U=\mu \mathrm{mol}$ citrulline or urea per hour; $\mathrm{g}=$ wet weight of liver in grams; $\mathrm{mgp}=\mathrm{mg}$ protein. of glucose-6-phosphatase. The results for this enzyme and for the four enzymes of the urea cycle proper fell within our control ranges for liver necropsy specimens for children. Our ranges for the activity of all the urea cycle enzymes compare well with those of Nuzum and Snodgrass (1976).

Volatile fatty acids in plasma and urine of baby $B$ were normal. Screening for urinary organic acids by paper chromatography gave negative results except that a small amount of lactic acid was present. Inspection of chromatograms under ultraviolet light showed a distinct uric acid spot, but no evidence of pyrimidine metabolites. Quantitative estimation of urinary orotic acid gave a level of $3.3 \mathrm{mmol} / \mathrm{mol}$ creatinine compared to a reference range of infants in the first week of life of $1 \cdot 5$ to $4 \cdot 7$. Using the same method, patients with OTC, argininosuccinic acid synthetase and lyase defects, even while clinically well on low protein diets, have given values over twice the upper limit of their reference range, and during episodes of increased ammonia levels, after illness or after protein intake, the urinary ratio has been from 100 to 1000 times that for normal children. The excretion of other pyrimidine metabolites, $\mathrm{N}$ carbamyl aspartate and $\mathrm{N}$-carbamyl $\beta$-alanine, were also measured and found to be within normal limits (Oberholzer and Palmer, 1976).

In a urine specimen with $\mathrm{pH}$ of 6.45 the ammonia level was $34 \mathrm{mmol} / 1(47 \cdot 6 \mu \mathrm{g} / 100 \mathrm{ml})$, with ammonia: urea ratio of $0 \cdot 24$. Upper limit for normal values for urine of same $\mathrm{pH}$ is $0 \cdot 11$.

\section{Discussion}

CPS deficiency seems to be one of the rarer enzyme defects of the urea cycle. Of the few cases reported, the diagnosis is doubtful in some. The first 2 cases to be described (Kirkman and Kiesel, 1969; Freeman et al., 1970) had unexplained hyperglycinaemia, and the primary defect in these patients has since been considered to be propionic acidaemia or methylmalonic acidaemia (Shih and Efron, 1972).

Hommes et al. (1969) and Arashima and Matsuda (1972) reported 2 females, 7 and 20 days old, both presenting with vomiting, lethargy, hypotonia, and irregular eye movements. The blood ammonia was slightly raised and a defect in CPS activity was found in each case. Older patients with partial defects in CPS activity have been described by Odièvre $e t$ al. (1973), Batshaw et al. (1975) and Gatfield et al. (1975).

Gelehrter and Snodgrass (1974) reported the first case of lethal neonatal hyperammonaemia due to complete absence of mitochondrial CPS, in a male infant who presented in the first 24 hours of life with hypothermia, irritability, and hypotonia and died at 
75 hours of age in coma. A similar case has recently been described by Formstecher (1976). Sheffield et al. (1976) recently described a case of neonatal hyperammonaemia presenting with pulmonary haemorrhage in which CPS deficiency was thought probable.

The 2 newborn infants described here represent another family in which neonatal death has apparently resulted from complete CPS deficiency. The clinical course of both babies was quite similar. In both, no milk was given and symptoms started at the beginning of the second day of life. Lethargy and hypotonia were the most prominent initial findings followed by convulsions and coma. Death occurred on the third and fourth day of life respectively.

Although enzyme studies were not done on baby A, it is reasonable to assume that the high blood ammonia was due to the same defect as in baby $\mathbf{B}$. The slight increase in SGOT in baby $A$ is not uncommon in cases of congenital hyperammonaemia and it appears that hyperammonaemia per se may have an adverse effect on hepatic function. Being aware of the possibility of a congenital defect of the urea cycle in baby B, we were able to do enzyme studies and to follow appropriate parameters from the first hours of life. Interestingly, in this baby there was a close relationship between the clinical course and the blood ammonia level (Table 1). It is apparent that symptoms did not appear until the blood ammonia reached $224 \mu \mathrm{mol} / 1(313.7 \mu \mathrm{g} / 100 \mathrm{ml})$.

Estimation of liver urea cycle enzymes in baby B at first showed a low OTC, but when repeated at more optimal conditions the level was within reference limits (Table 2). CPS activity was zero on both occasions. The repeat measurement was done with added OTC to ensure that there was adequate OTC activity for the coupled assay procedure used for CPS measurement (Snodgrass and DeLong, 1976). Loss during storage would not explain the complete absence of CPS activity. Normal levels of urea cycle enzymes in liver have been obtained after storage at $-70^{\circ} \mathrm{C}$ for 3 years (Brown et al., 1976). Raised urinary levels of pyrimidine metabolites are a feature of OTC deficiency (Levin, 1971; Shih and Efron, 1972) but not of CPS deficiency (Arashima and Matsuda, 1972). Urinary pyrimidine levels were not increased despite the gross hyperammonaemia present, suggesting that the primary defect was in the formation of carbamyl phosphate. The possibility of hyperammonaemia secondary to disorders of propionic or methylmalonic acid metabolism were ruled out by the normal blood and urine levels of these organic acids.

Both patients died soon after birth in spite of treatment, as did the patient of Gelehrter and Snodgrass who had complete CPS deficiency. In the reported cases with a prolonged clinical course, the CPS activities were between 13 and $50 \%$ of normal. It seems that an absence of mitochondrial CPS is incompatible with life.

The mode of transmission of CPS deficiency has not been clearly defined, and is complicated by doubts about the true diagnosis in the supposed cases. Final conclusions cannot be made until more families with the same enzyme defect have been studied. Meanwhile this condition, together with the other urea cycle defects, should be considered in the differential diagnosis of every infant with unexplained lethargy, convulsions, or coma.

We are grateful to Margaret Harris for measurements of orotic acid excretion, and to Queen Elizabeth Hospital Research Appeal Trust who supported this work in part.

\section{References}

Arashima, S., and Matsuda, I. (1972). A case of carbamyl phosphate synthetase deficiency. Tohoku Journal of Experimental Medicine, 107, 143-147.

Batshaw, M., Brusilow, S., and Walser, M. (1975). Treatment of carbamyl phosphate synthetase deficiency with keto analogues of essential amino acids. New England Journal of Medicine, 292, 1085-1090.

Brown, G., Jr., and Cohen, P. (1959). Comparative biochemistry of urea synthesis. I. Methods for the quantitative assay of urea cycle enzymes in liver. Journal of Biological Chemistry, 234, 1769-1774.

Brown, T., Hug, G., Lansky, L., Bove, K., Scheve, A., Ryan, M., Brown, H., Schubert, W. K., Partin, J. C., and Lloyd-Still, J. (1976). Transiently reduced activity of carbamyl phosphate synthetase and ornithine transcarbamylase in liver of children with Reye's syndrome. New England Journal of Medicine, 294, 861-867.

Formstecher, P. (1976). Experience personelle de la pathologie héréditaire du cycle de l'urée. MD thesis, Lille.

Freeman, J. M., Nicholson, J. F., Schimke, R. T., Rowland, L. P., and Carter, S. (1970). Congenital hyperammonemia; association with hyperglycinemia and decreased levels of carbamyl phosphate synthetase. Archives of Neurology, 23, 430-437.

Gatfield, P., Taller, E., Wolfe, D., and Haust, M. D. (1975). Hyperornithinemia, hyperammonemia and homocitrullinuria associated with decreased carbamyl phosphate synthetase 1 activity. Pediatric Research, 9, 488-497.

Gelehrter, T. D., and Snodgrass, P. J. (1974). Lethal neonatal deficiency of carbamyl phosphate synthetase. New England Journal of Medicine, 290, 430-433.

Hommes, F. A., de Groot, C. J., Wilmink, C. W. and Jonkis, J. P. (1969). Carbamyl phosphate synthetase deficiency in an infant with severe cerebral damage. Archives of Disease in Childhood, 44, 688-693.

Kirkman, H. N., and Kiesel, J. L. (1969). Congenital hyperammonemia. (Abst.) Pediatric Research, 3, 358-359.

Levin, B. (1971). Hereditary metabolic disorders of the urea cycle. Advances in Clinical Chemistry, 14, 65-143.

Levin, B., Abraham, J. M., Oberholzer, V. G., and Burgess, E. A. (1969). Hyperammonaemia; a deficiency of liver ornithine transcarbamylase. Archives of Disease in Childhood, 44, 152-161. 


\section{Mantagos et al.}

Nuzum, C. T., and Snodgrass, P. J. (1976). Multiple assays of the five urea cycle enzymes in human liver homogenates. The Urea Cycle, pp. 325-349. Ed. by S. Grisolia, F. Mayor, and R. Báguena. Wiley, New York.

Oberholzer, V. G., and Palmer, T. (1976). Increased excretion of $\mathrm{N}$-carbamoyl compounds in patients with urea cycle defects. Clinica Chimica Acta, 68, 73-78.

Odièvre, M., Charpentier, C., Cathelineau, L., Vedrenne, J., Delacoux des Roseaux, F., and Mercie, C. (1973). Hyperammoniémie constitutionelle avec déficit en carbamylphosphate-synthetase. Archives Françaises de Pédiatrie, 30, 5-13.

Palmer, T., Oberholzer, V. G., and Levin, B. (1974). Amino acid levels in patients with hyperammonaemia and argininosuccinic aciduria. Clinica Chimica Acta, 52, 335341 .

Rinderknecht, H., and Rinderknecht, J. (1965). A simple method for the quantitative determination of urinary pseudouridine and some new ultraviolet absorbing metabolites. Journal of Laboratory and Clinical Medicine, 65, 1034-1040.

Rogers, L. E., and Porter, F. S. (1968). Hereditary orotic aciduria. Pediatrics, 42, 423-428.

Scriver, C., and Rosenberg, L. E. (1973). Amino Acid
Metabolism and its Disorders, pp. 234-249. Saunders, Philadelphia.

Sheffield, L., Danks, D., Hammond, J., and Hoogenraad, N. (1976). Massive pulmonary hemorrhage as a presenting feature in congenital hyperammonemia. Journal of Pediatrics, 88, 450-452.

Shih, V. E., and Efron, M. L. (1972). Urea cycle disorders. The Metabolic Basis of Inherited Disease, 3rd ed., pp. 370392. Ed. by J. B. Stanbury, J. B. Wyngaarden, and D. S. Fredrickson. McGraw-Hill, New York.

Snodgrass, P. J. (1968). The effects of pH on the kinetics of human liver ornithine-carbamyl phosphate transferase. Biochemistry, 7, 3047-3051.

Snodgrass, P. J., and DeLong, G. R. (1976). Urea-cycle enzyme deficiencies and an increased nitrogen load producing hyperammonemia in Reye's syndrome. New England Journal of Medicine, 294, 855-860.

Stein, W. H., and Moore, S. (1954). The free amino acids of human blood plasma. Journal of Biological Chemistry, 211, 915-926.

Correspondence to Dr S. Mantagos, Department of Human Genetics, Yale University, 333 Cedar Street, New Haven, Connecticut 06510, USA. 